Mirosław Skarżyński

Uniwersytet Jagielloński, Kraków

miroslaw.skarzynski@gmail.com

\title{
POWSTANIE POLSKIEGO TOWARZYSTWA JĘZYKOZNAWCZEGO
}

Słowa klucze: historia polskiego językoznawstwa, Polskie Towarzystwo Językoznawcze Keywords: history of Polish linguistics, Polish Linguistic Society

1. Naukowe językoznawstwo polskie, które zaczęło się tworzyć w ostatnich dwudziestu kilku latach XIX w. w Krakowie, weszło w czas odradzania się porozbiorowej Polski z dorobkiem co prawda może niezupełnie na miarę ówczesnej europejskiej lingwistyki, ale jeśli zważyć, jaki był punkt wyjścia, to osiągnięty stan był całkowicie zadowalający. Trzeba tu liczyć rozwój badań nad językiem polskim i jego historią, prowadzone systematycznie badania dialektów, prace z zakresu indoeuropeistyki i językoznawstwa ogólnego, prace Komisji Językowej AU, językowe tomy Encyklopedii polskiej, „Rocznik Slawistyczny”, rozpoczęte prace nad Słownikiem staropolskim. Początki zrobił Lucjan Malinowski, ale decydującą rolę odegrali Jan Rozwadowski, Kazimierz Nitsch i Jan Łoś. Jeśli Malinowski umiał zachęcić kilku swych studentów (m.in. Nitscha, Romana Zawilińskiego, Jana Bystronia) do zainteresowania się sprawami językowymi, to wymienieni wcześniej trzej uczeni stworzyli językoznawczą szkołę krakowską. Właśnie uczniowie „krakowskiej trójcy” zasilili uniwersytety odradzającej się Polski (Lwów, Wilno, Poznańn). W 1918 r. istniało już środowisko

1 Do Lwowa przyszedł, po krótkim czasie pracy w Poznaniu, Tadeusz Lehr-Spławiński. W Wilnie znaleźli się Jan Otrębski i Edward Chomiński (ten drugi ze względu na chorobę nie odegrał większej roli), w Poznaniu prace podjęli Mikołaj Rudnicki i Edward Klich. Reaktywowany Uniwersytet Warszawski oparł się na miejscowych językoznawcach: Adamie Antonim Kryńskim 
fachowych badaczy języka i języków, co więcej, trzej krakowscy uczeni mieli jasno sprecyzowane plany rozwoju dyscypliny w nowych warunkach, organizacji instytucjonalnej polskiej lingwistyki i perspektywy badawcze, co dobrze było widać w ich wypowiedziach w ankiecie rozpisanej w 1917 r. przez Komitet Kasy Mianowskiego wśród polskich uczonych (Skarżyński 2014). Nitsch liczył w 1918 r. środowisko polskich (czynnych) językoznawców na ok. 20 osób (ibid.).

W $1921 \mathrm{r}$. Nitsch urzeczywistnił swój pomysł, o którym wspomniał w referacie trzy lata wcześniej ${ }^{2}$. Wspólnie z Rozwadowskim i Łosiem utworzyli Towarzystwo Miłośników Języka Polskiego, mające propagować wiedzęo języku polskim i skupiać ludzi zainteresowanych polszczyzną oraz jej poprawnością, niezależnie od ich profesji. Była to organizacja „szeroko założona”, nie zaś gromadząca wyłącznie uczonych.

Przed rokiem 1918 na ziemiach polskich działało pięć towarzystw naukowych „ogólnych”, co znaczy tu, że ich członkami były osoby zajmujące się rozmaitymi dziedzinami nauki w sposób mniej lub bardziej systematyczny ${ }^{3}$, oraz osiemnaście towarzystw ,jednodyscyplinarnych”, m.in. Towarzystwo Filologiczne (założone w 1893)4, Towarzystwo Filozoficzne (1904), Towarzystwo Historyczne (1886), Towarzystwo Ludoznawcze (1895), Stowarzyszenie Badaczy i Miłośników Poezji A. Mickiewicza (1886, potem Towarzystwo Literackie im. Adama Mickiewicza), Towarzystwo Przyrodników im. Mikołaja Kopernika (1875) i in., wśród nich ekonomiczne i medyczne. Liczba ta zaczęła się powiększać już w pierwszych latach niepodległości. Między innymi z inicjatywy trójki profesorów Uniwersytetu Jana Kazimierza: Jana Czekanowskiego, Andrzeja Gawrońskiego i Zygmunta Smogorzewskiego, powstało we Lwowie w 1922 r. Polskie Towarzystwo Orientalistyczne.

Drugi z założycieli PTO, Andrzej Gawroński, był pomysłodawcą, jak podaje Stanisław Urbańczyk (1959), zorganizowania także Polskiego Towarzystwa Językoznawczego.

(studia w Szkole Głównej Warszawskiej i w Lipsku), Karolu Applu (samouku), Stanisławie Szoberze (studia na Cesarskim Uniwersytecie Warszawskim, potem w Moskwie), Tytusie Bennim (studia w Lipsku, doktorat we Fryburgu, habilitacja na Uniwersytecie Jagiellońskim) oraz na powracających z Rosji, Janie Baudouinie de Courtenay i Wiktorze Porzezińskim.

2 „»)̨zyk polski«, w zasadzie jak wymieniony wyżej, ale stanowczo rozszerzony, służyć winien szerszym warstwom wykształconym różnych zawodów, zwłaszcza jednak nauczycielstwu; dlatego, prócz naukowej popularyzacji, mógłby mieć i dział gramatyki stosowanej (szkolnej, także odpowiedzi na pytania). Szłoby tu o szerzenie wiedzy językowej w ogóle, ale z natury rzeczy na pierwszym planie stałby język polski. Dobrze by było oprzeć go o szeroko założone »Towarzystwo językoznawcze«, czy »Tow. miłośników języka«, które przecież mogłoby mieć w Polsce z tysiąc członków, otrzymujących za wkładkę pismo; [...]” (Nitsch 1918: 365-366).

3 Były to: Poznańskie Towarzystwo Przyjaciół Nauk (założone w 1857), Towarzystwo Naukowe Płockie (1820, reaktywowane 1907), Towarzystwo Naukowe w Toruniu (1875), Towarzystwo Naukowe Warszawskie (kontynuujące od 1907 r. tradycje Towarzystwa Przyjaciół Nauk w Warszawie (1800-1832)), Towarzystwo Przyjaciół Nauk w Przemyślu (1909).

Po odzyskaniu niepodległości towarzystwa dodały w nazwie przymiotnik polskie. 
2. Dokładny opis samych początków PTJ nie jest możliwy z powodu dość zasadniczego - fatalnego niedostatku materiałów źródłowych, bez których nie da się pisać historii. Jedynym źródłem jest zeszyt protokołów zebrań zarządów PTJ, obejmujący lata 1925-19645. Zapisy w nim są jednak tak lakoniczne, że przynoszą niewiele informacji. Taki sposób protokołowania przebiegu zebrań stosowali zresztą wszyscy sekretarze w następnych dziesięcioleciach. W tym wypadku trudno cieszyć się z owej „chwalebnej zwięzłości”, bo to, co było dogodne dla piszących owe protokoły, stało się nieszczęściem dla potencjalnych badaczy dziejów Towarzystwa. Mamy jeszcze drobne wzmianki w listach Baudouina de Courtenay do Henryka Ułaszyna (Skarżyński, Smoczyńska 2007) oraz w listach Nitscha i Rozwadowskiego do tego samego adresata (Czelakowska, Skarżyński 2011)6. Urbańczyk (1993) PTJ poświęcił zaledwie kilkanaście linijek, dość ogólnikowych. Niczego do poznania początków Towarzystwa nie wnoszą także rocznicowe artykuły w „Biuletynie PTJ” (Milewski 1966; Urbańczyk 1971; Zaleski 1975), ukierunkowane naturalnie na najogólniejsze przypomnienie tego czy innego okresu działalności Towarzystwa?.

Siłą rzeczy ten artykuł będzie szkicem, który przyniesie jedynie najogólniejsze wyobrażenie o początkach Towarzystwa. Nie pozostaje nic innego, jak wykorzystać to, co jest, i na tyle, na ile to możliwe, i spróbować zrekonstruować zajmujące nas wydarzenie, unikając zbyt daleko idących domysłów.

3. Nie wiemy, kiedy się zrodził pomysł założenia Towarzystwa - być może w 1923 r., ale to tylko przypuszczenie oparte na akapicie listu Gawrońskiego do Nitscha, w którym mowa o planowanym spotkaniu w Krakowie.

[...] Pewnie Ci już pisał Szober, że chcielibyśmy urządzić także maleńki zjazd u Was w dwa pierwsze świąteczne dni listopadowe. Myślę, że przyjadę. Daj tylko znać, czy będziecie. Z Warszawy wybiera się Porzeziński i Szober, z którym we trzech powzięliśmy [wyraz nieczytelny]; stąd Lehr (Spuścizna KN, list z 12 X 1923 r.).

Nie wiemy, czy doszło do owego „zjazdu”, ponieważ w późniejszych listach z roku 1923 brak jakiejkolwiek wzmianki na ten temat. Wiemy natomiast, że do spotkania pomysłodawcy z krakowskimi uczonymi doszło wiosną 1924 r. Zapewne wówczas

5 Archiwum Nauki PAU i PAN w Krakowie, sygn. K I-22. W teczce oprócz owego zeszytu jest tylko egzemplarz pierwszego Statutu PTJ.

6 Nie wykluczam tego, że jakieś informacje mogą być w dotychczas nieprzebadanych spuściznach innych językoznawców z tamtych czasów.

7 Nb. nie ma hasła „Polskie Towarzystwo Językoznawcze” w Wikipedii, gdzie kategoria „Polskie towarzystwa naukowe" liczy 131 pozycji. Nigdy nie podjęto próby opisania historii Towarzystwa, nawet z okazji jego 75-lecia. Trzeba też zauważyć, że już sama monografia „Biuletynu PTJ”, oparta na analizie referatów i artykułów, byłaby wartościowym wkładem do historii polskiego językoznawstwa, pokazałaby bowiem zmiany zachodzące w dyscyplinie i trendy badawcze na przestrzeni kilkudziesięciu lat.

8 Niepewność Gawrońskiego to skutek jego stanu zdrowia w tym czasie. 
poczyniono konkretniejsze ustalenia, również w sprawie opracowania statutu przyszłego towarzystwa, i albo powierzono tę pracę Gawrońskiemu, albo też on sam ofiarował się ją wykonać. Dowodem na to jest list Nitscha do Ułaszyna z 22 XI 1924 r.:

Szanowny Panie Kolego!

Posyłam Panu projekt statutu Tow[arzystwa] Językoznawczego, pióra Gawrońskiego. Ułożony jest w myśl naszych obrad wiosennych, wskutek czego wątpliwości są tylko w szczegółach. Rozważyłem je z Rozwadowskim i Porzezińskim i teraz posyłamy Panu. [...] $]^{9}$

Ze względu na trudność zebrania się razem w jednym miejscu wszystkich członków delegowanych do statutu (Gawr[oński], Rozw[adowski], Porzez[iński], Uł[aszyn], Nitsch), proponuję, by się Pan nie upierał przy ewentualnych dalszych odmiennych swych zapatrywaniach, a ograniczył się do rzeczy istotnych, bo inaczej trudno by było wnieść projekt do władz, co by trzeba zrobić jeszcze w tym roku kalendarzowym.

Oczywiście proszę o zwrot załączonego projektu, bo to jedyny egzemplarz (Czelakowska, Skarżyński 2011: 278-279).

Z drugiego akapitu cytowanego listu wynika, że grupa inicjatywna liczyła więcej osób, skoro wymieniona przez Nitscha piątka językoznawców została delegowana do prac nad statutem. Poza krakowskim były przecież środowiska językoznawcze w Warszawie, Poznaniu i Lwowie ${ }^{10}$, a takie przedsięwzięcie jak zorganizowanie towarzystwa naukowego wymagało szerszego porozumienia. Nie sposób dziś ustalić składu owej grupy, ale nie utożsamiałbym jej z uczestnikami walnego zebrania organizacyjnego, o którym dalej.

Z listu Nitscha wynika, że prace nad statutem trwały długo, zapewne z powodu Ułaszyna i jego dość szczególnego charakteru. Niewykluczone też, że mimo prośby Nitscha także później forsował on jakieś swoje zastrzeżenia, statut bowiem trafił do urzędu wojewódzkiego w Krakowie 16 lutego 1925 r., a więc dopiero w sześć miesięcy po napisaniu cytowanego listu (Statut 1925).

3.1. Nie wchodząc szczegółowo w treść statutu, ograniczę się do zwrócenia uwagi na dwie rzeczy.

Po pierwsze, celem PTJ miało być przyczynianie się do „rozwoju wiedzy językoznawczej”, co zamierzano realizować przez „podejmowanie i popieranie wydawnictw naukowych”, „podejmowanie i popieranie badań językoznawczych”, „ułatwienie i podtrzymywanie stosunków i łączności wśród swych członków, jako też ich stosunków z zagranicą” oraz „urządzanie zjazdów, posiedzeń i odczytów naukowych" (ibid.).

9 W tym miejscu opuszczam przytoczone przez Nitscha niektóre paragrafy statutu wraz z poprawkami.

10 W Wilnie wtedy był tylko Jan Otrębski.

11 Dla porównania analogiczne paragrafy obecnego Statutu PTJ:

„\$5 1. Celem Towarzystwa jest przyczynianie się do rozwoju wiedzy językoznawczej, ze szczególnym uwzględnieniem wartościowych ustaleń naukowych oraz nowatorskich rozwiązań praktycznych. 
Jak pisze Urbańczyk (1993: 181) w odniesieniu do okresu międzywojennego, PTJ ograniczało się do organizacji zjazdów i wydawania „Biuletynu”. Jednak z pojedynczych wzmianek w korespondencji językoznawców wiadomo o dwóch wystąpieniach Towarzystwa do Ministerstwa Wyznań Religijnych i Oświecenia Publicznego w sprawie przyznania zasiłków kilku językoznawcom, by mogli wziąć udział w I Międzynarodowym Kongresie Slawistów w Pradze w 1929 r. (list Nitscha do Ułaszyna; Czelakowska, Skarżyński 2011: 294) i w II Międzynarodowym Kongresie Lingwistów w Genewie w 1931 r. (list Rozwadowskiego do Ułaszyna; ibid.: 388). Dalej, 26 lutego 1928 r., Zarząd na dziesiątym posiedzeniu zdecydował o wystąpieniu do MWRiOP z prośbą, by zakupiło ono 100 egzemplarzy „Biuletynu” i przeznaczyło je do rozdania przez polskich delegatów wśród uczestników zjazdu językoznawczego w Hadze. Były to bardzo skromne próby „promocji polskiej nauki za granicą”, ale świadczą o tym, że w ciężkich czasach kryzysu gospodarczego starano się choć tyle zrobić.

Rzecz druga to członkostwo Towarzystwa. Otóż według zapisu w \$5. członkiem PTJ mogła zostać „osoba pełnoletnia sprzyjająca celom Tow[arzystwa]” ${ }^{{ }_{12}}$, na wniosek pisemny poparty przez co najmniej dwóch członków PTJ, która w tajnym głosowaniu Zarządu otrzymała większość bezwzględną głosów. Tak więc pierwotnie nie stawiano warunku uprawiania lingwistyki, wystarczało samo poparcie celów, dla których PTJ powstało. Taki zapis czynił Towarzystwo organizacją otwartą na wzór wielu innych, wcześniej istniejących towarzystw naukowych. Myli się więc Urbańczyk, gdy pisze: „Drugie z nich [tj. PTJ - M.S.] zrzeszało zawodowych językoznawców" (1993: 180). Stanowili oni bez wątpienia większosśc członków, ale nie całość.

Pierwszy statut PTJ zawierał także zapis, by co roku przed Walnym Zgromadzeniem z Zarządu ustępowało trzech członków wskazanych w losowaniu. Na ich

2. Do osiągnięcia swego celu zmierza Towarzystwo przez:

1) upowszechnianie i popularyzację osiągnięć językoznawczych,

2) ułatwianie i podtrzymywanie kontaktów i łączności wśród swych członków oraz kontaktów z ośrodkami i stowarzyszeniami naukowymi za zagranicą,

3) urządzanie zjazdów, sesji naukowych, seminariów, posiedzeń i odczytów naukowych,

4) wydawanie periodyku naukowego pt. „Biuletyn Polskiego Towarzystwa Językoznawczego”,

5) publikację wydawnictw,

6) organizację wykładów i dyskusji o charakterze naukowo-badawczym” (ptj.civ.pl/pl/dokumenty/; dostęp: 26 IV 2016).

12 Zapis ten zmieniono w Statucie PTJ przyjętym przez Walne Zgromadzenie 7 kwietnia $1956 \mathrm{r}$. na: „Członkiem Towarzystwa może być osoba pełnoletnia z wykształceniem językoznawczym” (wyróżn. M.S., Statut 1956) W późniejszym czasie warunek doprecyzowano: „1. Członkami zwyczajnymi mogą być pracownicy nauki, naukowo-dydaktyczni, nauczyciele, pracownicy instytucji wydawniczych i oświatowych oraz inne osoby działające w dziedzinie językoznawczej, pragnące uczestniczyć w realizacji celów Towarzystwa i wykazujące się aktywnością naukową, udokumentowaną przynajmniej trzema pracami naukowymi opublikowanymi lub przyjętymi do druku; od wymogu tego przewiduje się uzasadnione wyjątki dla osób odznaczających się szczególnymi osiągnięciami w dziedzinie językoznawstwa" (ptj.civ.pl/pl/dokumenty/; dostęp 26 IV 2016). 
miejsce Zgromadzenie wybierało trzech nowych. Umożliwiało to w dłuższej perspektywie zaangażowanie do pracy w Zarządzie większej liczby członków Towarzystwa, choć na przeciążenie pracą nikt chyba nie mógł narzekać. Wspomniany zapis został później zniesiony.

3.2. Walne zebranie organizacyjne, z przewidzianą także częścią naukową, zwołano na 31 maja 1925 r. do Lwowa ${ }^{13}$. Nastąpiło to nieco nagle i zaskoczyło część zainteresowanych. Także zaskoczeniem była owa część naukowa. 28 kwietnia Ułaszyn pisał do Nitscha:

Szanowny Panie Kolego!

W sobotę otrzymałem kartę z zapowiedzią druków, a w poniedziałek (27 IV) druki (statut etc.).

Naturalnie zaraz postarałem się rozdać; wszakże dostali wszyscy dopiero dziś, tj. we wtorek. Zafrapowało nas bardzo tak późne zawiadomienie o zjeździe z referatami. Spodziewaliśmy się tylko walnego zebrania, a jeśli kto myślał o zjeździe, to nie o innym, niż jaki był w roku zeszłym ${ }^{14}$. Przecież dopiero Towarzystwo miało się takim zjazdem zająć. Pierwszy zjazd i robiony takim „gwałtem” - to nam się nie bardzo podoba. W ogóle powstały wszelakie wątpliwości; tak że zdecydowałem z Rudnickim zwołać na czwartek porozumiewawcze zebranie. Potem więc obszerniej napiszę (Czelakowska, Skarżyński 2011: 135).

Niestety, nie wiadomo, jaki był przebieg owego „porozumiewawczego zebrania”, natomiast zapewne na nim poznaniacy zdecydowali o nieuczestniczeniu w lwowskim zgromadzeniu, co się też stało. Refleks tego incydentu mamy w liście Baudouina de Courtenay do Ułaszyna, pisanym 24 czerwca 1925 r.:

Byłem na zjeździe językoznawczym we Lwowie i doszedłem do wniosku, że Panowie z Poznania niesłusznie go zbojkotowali. W ogóle zjazd się udał i prawdopodobnie da dodatnie rezultaty. Omawiano plan dalszej pracy, wymieniano zadania Towarzystwa itd. W przeddzień samego zjazdu urządzono posiedzenie Tow[arzystwa] Mił[ośników] J[ęzyka] P[olskiego], na którym Nitsch miał referat z dość obszerną dyskusją. Po południu w dzień zjazdu miał interesujący referat Porzeziński, a to dało również powód do dyskusji. Uczestnicy zjazdu fotografowali się zbiorowo w liczbie 23 członków i członkiń, ale to oczywiście nie świadczy ani za, ani przeciw użyteczności samego zjazdu (Skarżyński, Smoczyńska 2007).

4. Walne zebranie organizacyjne 23 członków Towarzystwa odbyło się 31 maja 1925 r. w sali Seminarium Filologii Słowiańskiej Uniwersytetu Jana Kazimierza we Lwowie. Otworzył je jako przedstawiciel gospodarzy Tadeusz Lehr-Spławiński. Obecni byli:

13 Miejsce zaproponował Gawroński, zob. list do Nitscha z 15 IV 1925 r. (Spuścizna KN).

14 Użycie tu przez Ułaszyna słowa „zjazd” w odniesieniu do zebrania grupy inicjatywnej jest nieco przesadne.

15 W spuściźnie Nitscha nie ma listu Ułaszyna „obszerniej” rzecz wyjaśniającego. 
Ze Lwowa (1o osób): Zygmunt Czerny, Andrzej Gawroński, Henryk Gaertner, Janina Heydzianka ${ }^{16}$, Jan Janów, Tadeusz Lehr-Spławiński, Maria Rytarowska ${ }^{17}$, Eugeniusz Słuszkiewicz, Stanisław Witkowski, Jan Ziłynski.

Z Warszawy (6): Jan Baudouin de Courtenay, Witold Doroszewski, Zygmunt Łempicki, Wiktor Porzeziński, Stefan Saski ${ }^{18}$, Stanisław Szober.

Z Krakowa (6): Piotr Jaworek, Zenon Klemensiewicz, Kazimierz Nitsch, Jan Łoś, Henryk Oesterreicher, Jan Rozwadowski.

Z Wilna (1): Jan Otrębski.

Tak też odnajdujemy ich na znanej fotografii: w pierwszym rzędzie siedzą seniorzy polskiej lingwistyki, za nimi stoi „młodzież”.

Na honorowego przewodniczącego zebrania wybrano Baudouina, realnym, czyli prowadzącym obrady, został Rozwadowski.

4.1. W pierwszej, organizacyjnej części zebrania zajęto się czterema kwestiami: wyborem Zarządu i Komisji Rewizyjnej, planowanym czasopismem, przyszłą pracą Towarzystwa i ustaleniem tematyki pierwszego zjazdu.

W Sprawozdaniu wydrukowanym w pierwszym numerze „BPTJ” podaje się, że Rozwadowski, objąwszy przewodnictwo, „skreślił pokrótce historię zabiegów około zorganizowania Towarzystwa na tle stosunków, jakie zapanowały w pierwszych latach powojennych" (Sprawozdanie: 85), o czym brak wzmianki w protokole (Zeszyt). Szkoda oczywista, że Jan Janów, który był sekretarzem walnego zebrania, nie zanotował choćby w punktach wystąpienia Rozwadowskiego, przepadło bowiem jedyne zapewne bezpośrednie źródło informacji o wstępnym etapie organizacji PTJ.

Do wyłonionego przez głosowanie ogólne dziewięcioosobowego Zarządu PTJ weszli:

- z Krakowa: Tadeusz Kowalski, Jan Łoś, Jan Rozwadowski, Stanisław Wędkiewicz,

- ze Lwowa: Tadeusz Lehr-Spławiński,

- z Poznania: Adam Kleczkowski i Mikołaj Rudnicki,

- z Warszawy: Wiktor Porzeziński i Stanisław Szober.

Jak widać, zabrakło w Zarządzie przedstawiciela Wilna, w tym wypadku Otrębskiego. Komisję Rewizyjną składali: Piotr Jaworek, Zenon Klemensiewicz i Kazimierz Nitsch.

16 Janina Heydzianka-Pilatowa (1899-1986), w tym czasie już absolwentka UJK, slawistka, w dwa lata później obroniła doktorat napisany pod kierunkiem Lehra-Spławińskiego. Do 1939 r. nauczycielka w gimnazjum we Lwowie, od 1945 r. w Anglii - profesor Polskiego Uniwersytetu na Obczyźnie (PUNO) (Urbańczyk 1987). Zajmowała się językiem Drzewian połabskich. Jako pierwsza z polskich badaczy zainteresowała się pracami Bronisława Malinowskiego.

17 Maria Rytarowska, polonistka, absolwentka UJK, nauczycielka lwowskich gimnazjów, w latach 1933-1936 dyrektorka gimnazjum przy klasztorze benedyktynek. Żona indoeuropeisty prof. Eugeniusza Słuszkiewicza, po wojnie pracownik naukowy Uniwersytetu Mikołaja Kopernika w Toruniu, w Katedrze Dydaktyki Języka i Literatury Polskiej, autorka podręczników szkolnych.

18 Stefan Saski (1888-1974), uczeń Nitscha, Łosia i Rozwadowskiego. W latach międzywojennych nauczyciel gimnazjów warszawskich, od 1945 r. pracownik Uniwersytetu Poznańskiego (UAM), autor wielu haseł Słownika polszczyzny XVI wieku. 
Wybierając Zarząd PTJ, nie pominięto nieobecnego środowiska poznańskiego. W głosowaniu przeszli Rudnicki (19 głosów) i Kleczkowski (18), nie przeszedł natomiast, niekoniecznie lubiany w środowisku, Ułaszyn (5 głosów) ${ }^{19}$.

Jak się wydaje, nie przyjęto pierwotnej propozycji Andrzeja Gawrońskiego, by w Zarządzie byli reprezentowani w równej liczbie przedstawiciele różnych dziedzin językoznawstwa (Zeszyt) i wybierano chyba po prostu spośród zgłaszanych z sali kandydatur.

Prezydium Zarządu PTJ ukonstytuowało się później, podczas zebrania Zarządu w Krakowie 28 czerwca 1925 r. Przewodniczącym („prezesem” - Zeszyt) Towarzystwa został Rozwadowski, zastępcą Porzeziński, skarbnikiem Kowalski, a sekretarzem Szober.

4.2. W sprawie czasopisma uchwalono stworzenie biuletynu, którego tytuł został ustalony dopiero na trzecim posiedzeniu Zarządu, w Krakowie 15 lutego $1926 \mathrm{r}$. (Zeszyt): „Biuletyn Polskiego Towarzystwa Językoznawczego / Bulletin de la Société polonaise de linguistique”. Na pierwszym posiedzeniu Zarządu (28 czerwca $1925 \mathrm{r}$.) powołano Komitet Redakcyjny, do którego weszli Nitsch, Porzeziński, Rozwadowski i Wędkiewicz (ibid.).

W punkcie dotyczącym biuletynu wywiązała się dyskusja nad językiem publikacji zainicjowana przez Baudouina. Protokół odnotowuje głos Gawrońskiego, optującego za językiem polskim z uwagi na to, że pismo przeznaczone ma być „dla środowiska polskiego" i głos Nitscha: „polski, bo niełatwo u nas pisać w obcych językach”. Prawdopodobnie były i inne głosy, a być może i spory, skoro w protokole zanotowano propozycję (nie wiadomo czyją), by rzecz pozostawić do rozstrzygnięcia Komitetowi Redakcyjnemu. Ostatecznie jednak przyjęto język polski jako podstawowy, ale $\mathrm{z}$ dopuszczeniem także innych języków (Zeszyt).

4.3. Protokół notuje wystąpienie Baudouina w sprawie zadań powstałego Towarzystwa. Podane są w punktach wątki, co do których uczony uważał, że powinno się je uwzględnić w przyszłych pracach. Znajdujemy tu zagadnienia, którymi Baudouin sam się zajmował: „opracowanie fonetyki i opis zmian morfologicznych na tle fonetyki”, embriologia i patologia języka, mieszanie się języków, badania języków sztucznych, niejasno sformułowany punkt „wyzyskanie materiału, który daje język”. Są też propozycje nowe, ujęte przez Baudouina w obszerny blok szczegółowszych zagadnień, nazwany „inwentaryzacja pewnych części myślenia językowego, np. dezyderatów w zakresie j. polskiego...”. Te szczegółowsze wątki to badania homonimii, synonimia rdzeni i sufiksów w epoce indoeuropejskiej i polskiej, co - jak się wydaje

19 Być może w tym niepowodzeniu wyborczym leży przyczyna niebrania przez Ułaszyna udziału w Zjazdach PTJ oraz braku w jego wspomnieniach (Ułaszyn 2010) najmniejszej nawet wzmianki o Towarzystwie, choć nie brak w nich opisów jego aktywności w rozmaitych innych organizacjach, znacznie mniej ważnych. Jeśli pamiętać o wyjątkowej drażliwości Ułaszyna w ogóle, a na swym punkcie w szczególności, taki powód wydaje się możliwy. 
z lakonicznych zapisów - powinno doprowadzić do powstania słownika (w protokole: „wykaz”) morfemów, w układzie od końcowych pozycji w strukturach wyrazowych „według wymawianiowo-słuchowych właściwości końcówek”. To ostatnie sformułowanie, bez wątpienia bezpośrednio Baudouinowskie, jest jednak niejasne.

Propozycje Baudouina są jedynymi zgłoszonymi na zebraniu pomysłami odnoszącymi się do przyszłych prac Towarzystwa, które zapisano w protokole. Jak wiemy, PTJ nie prowadziło prac badawczych, a nawet nie koordynowało badań w Polsce prowadzonych, więc rzecz pozostała bez kontynuacji.

4.4. Ostatnim punktem organizacyjnej części zebrania było zaproponowanie przez Rozwadowskiego tematyki pierwszego zjazdu Towarzystwa, planowanego na rok 1926: „Walka idealizmu z empiryzmem” (ostateczna wersja: „Idealizm i pozytywizm w językoznawstwie") ${ }^{20}$.

4.5. Na zebraniu organizacyjnym ustalono także wysokość składki członkowskiej na 24 zł. Nie była to kwota bagatelna, co wkrótce potwierdziło zaleganie z jej płatnością przez część członków. O zaległościach informował już na drugim zebraniu Zarządu (14 grudnia 1925 r.) skarbnik Tadeusz Kowalski. Na trzecim zaś zebraniu Zarządu (15 lutego 1926 r.) został przedstawiony list dyrektora gimnazjum w Pińczowie, Chmielowca ${ }^{21}$, o rezygnacji z członkostwa z powodu „niemożności opłacenia składki wobec redukcji przez MWRiOP pensji nauczycieli gimnazjów" (Zeszyt) 22 .

$\mathrm{Na}$ część naukową, która nastąpiła po uregulowaniu spraw organizacyjnych, złożyły się: relacja J. Rozwadowskiego z międzynarodowego zjazdu językoznawczego w Kopenhadze poświęconego opracowaniu międzynarodowego alfabetu fonetycznego oraz referat W. Porzezińskiego Locativus singularis w języku litewskim. W protokole nie zanotowano przebiegu dyskusji nad referatem Porzezińskiego.

5. Jak powiedziano wyżej, w zebraniu organizacyjnym PTJ wzięły udział 23 osoby, w większości będące językoznawcami. W 1926 r. Towarzystwo liczyło 53 członków, w 1929 - 65, w 1934 - 58, w 1935 - 54, w 1937 - 53, w 1938 - 51 $1^{23}$. Dopiero po II wojnie, w miarę powiększania się liczby językoznawców w Polsce, systematycznie zwiększała się też liczebność Towarzystwa.

20 Zjazd ten nie odbył się w zaplanowanym terminie z powodu zamachu majowego i został przesunięty na rok 1927.

21 W odnośnym protokole brak imienia, a samego Chmielowca nie ma już w pierwszym spisie członków PTJ za rok 1926.

22 Na siódmym zebraniu Zarządu, 20 III 1927 r., podjęto po raz pierwszy decyzję o skreśleniu z listy członków osób zalegających ze składkami. Skreślono wówczas Stanisława Bąka, Władysława Chodaczka, Romana Kubińskiego, Juliusza Ramberga, Stefana Saskiego, Juliusza Zborowskiego, Janinę Heydziankę, Zygmunta Arendta-Choińskiego, Tassilo Schultheissa (członka zagranicznego z Berlina). Jak widać, kłopoty z niepłacącymi składek członkami były od samego początku istnienia Towarzystwa, a wobec tego wypadałoby uznać je może za składnik tradycji PTJ? Według list członków publikowanych w kolejnych tomach „BPTJ”. 


\section{Literatura}

Czelakowska A., Skarżyński M., 2011, Materiały do dziejów polskiego językoznawstwa. Listy Jana Niecisława Baudouina de Courtenay, Jana Łosia, Kazimierza Nitscha, Jana Michała Rozwadowskiego, Henryka Ułaszyna, „Biblioteka LingVariów”, t. 8, Kraków.

Milewski T., 1966, Działalność naukowa Polskiego Towarzystwa Językoznawczego w 2o-leciu $P R L$, ,Biuletyn Polskiego Towarzystwa Językoznawczego” XXIV, s. 9-16.

Nitsch K., 1918, Organizacja i potrzeby nauki w dziale języka polskiego, „Nauka Polska. Jej Potrzeby, Organizacja i Rozwój”, t. I, s. 355-366.

SKARŻYŃSKi M., 2014, „W jaki sposób wzmocnić u nas językoznawstwo?”. Lingwistyka polska w wypowiedziach uczonych z lat 1918-1919, „LingVaria” nr 2 (18), s. 251-270.

SkARżyński M., Smoczyńska M. (oprac.), 2007, Listy Jana Baudouina de Courtenay do Henryka Ułaszyna z lat 1898-1927, „Biblioteka LingVariów”, t. 1, Kraków.

Sprawozdanie: Sprawozdanie z I walnego zebrania członków P.T.J., „Biuletyn Polskiego Towarzystwa Językoznawczego" I, 1927, s. 84-85.

SPuścizna KN: Spuścizna Kazimierza Nitscha, Archiwum Nauki PAN i PAU w Krakowie, sygn. K III-51, Korespondencja przychodząca, j. 189, Listy Andrzeja Gawrońskiego.

STATUT 1925: Statut Polskiego Towarzystwa Językoznawczego, przyjęty do wiadomości przez Województwo w Krakowie pismem z 16 lutego 1925, nr 1898/I/pr., „Biuletyn Polskiego Towarzystwa Językoznawczego" I, 1927, s. 80-84.

STATUT 1956: Statut Polskiego Towarzystwa Językoznawczego, „Biuletyn Polskiego Towarzystwa Językoznawczego" XV, 1956, s. 211-214.

UŁAsZYN H., 2010, Z Kopiowatej na katedry uniwersyteckie. Wspomnienia. Z rękopisu opracował, przypisami opatrzył i wydał M. Skarżyński, „Biblioteka LingVariów”, t. 7, Kraków.

URBAŃ́CZY S., 1959, Jan Rozwadowski (próba charakterystyki), [w:] J. M. Rozwadowski, Wybór pism, t. 1: Pisma polonistyczne, s. 7-27, Warszawa.

URваŃCZyк S., 1971, Dwadzieścia pięć lat Polskiego Towarzystwa Językoznawczego w Polsce Ludowej (skrót przemówienia na otwarciu 28 Zjazdu PTJ), „Biuletyn Polskiego Towarzystwa Językoznawczego" XXVIII, s. 215-218.

Urbańczy K S., 1987, Śp. Janina Heydzianka-Pilatowa (2o XI 1899-24 X 1986), „Język Polski” LXVII, s. 161-163.

UrbańcZy к S., 1993, Dwieście lat polskiego językoznawstwa (1751-1950), Kraków.

ZALeski J., 1975, 50 lat działalności Polskiego Towarzystwa Językoznawczego, „Biuletyn Polskiego Towarzystwa Językoznawczego" XXXVIII, s. 23-28.

Zeszyt: [Zeszyt protokołów zebrań Zarządu PTJ], Archiwum Nauki PAN i PAU w Krakowie, sygn. K I-22.

\section{The foundation of the Polish Linguistic Society Summary}

In 1924, Andrzej Gawroński, a professor at the John Casimir University, a linguist, and an Indian philologist, postulated the creation of a scientific society for linguistics. The project was accepted by the then few circles of Polish linguists, and steps have been taken toward its realization. On $31^{\text {st }}$ May 1925, the founding meeting was held in Lviv and formally brought to life the Polish Linguistic Society. Based on the vestigial extant sources, this paper presents, to what degree it is possible, this episode in the history of Polish linguistics. 